\title{
Analisis Pengaruh Ekuitas Merek, Preferensi Merek, dan Harga Dengan Citra Negara Asal Sebagai Variabel Moderasi Terhadap Minat Pembelian Laptop Oleh Mahasiswa Di Kota Batam
}

\author{
Lily Purwianti \\ Universitas Internasional Batam \\ lpurwianti@yahoo.com \\ Mehdar Badrus Zaman \\ Universitas Internasional Batam \\ Lpurwianti@yahoo.com
}

\begin{abstract}
The main purpose of this study is to investigate the relationships among brand equity, brand preference, price and purchase intention. Moreover secondary aim of this research is examining the moderate role of country of origin image. Independent variables used in this research are brand equity, brand preference and price. Data were collected from 500 students in Batam who recognized the selected brand of laptop using judgmental sampling from 5 universities they are Universitas Putera Batam, Universitas Riau Kepulauan, Politeknik Negeri Batam, Universitas Internasional Batam, and Universitas Batam. Hypotheses were tested using SPSS program version 21. Results indicated that brand equity, brand preference and price positively influence consumer's purchase intention. But results unsupported moderating role of country of origin image in the relationships among brand equity, brand preference and purchase intention.
\end{abstract}

Keywords: brand equity, brand preference, price, country of origin and purchase intention.

\section{Pendahuluan}

Sebagian besar perusahaan memiliki tujuan untuk menarik perhatian konsumen. Salah satu cara untuk mencapai tujuan tersebut adalah dengan membuat perbedaan pada suatu produk. Perusahaan dapat membuat perbedaan dengan dua acara, yaitu secara fisik (rasa, desain produk, dsb) dan non fisik (harga, nama merek, dan citra negara asal). Pemberian merek merupakan proses penting dalam hal perbedaan suatu produk. Hal tersebut dikarenakan melalui merek itulah, produsen dapat memperoleh keuntungan dari penjualan produk yang unik dan berkualitas serta dapat mengkomunikasikan hubungan antara merek tersebut dengan barang atau jasa. (Moradi dan Zarei, 2011).

Merek yang kuat dapat memberikan sebuah keunggulan kompetitif, meningkatkan arus kas, menyesuaikan likuiditas, menaikkan harga, meningkatkan profitabilitas dan loyalitas pelanggan, serta memberikan kesempatan bagi perusahaan untuk melakukan brand extension. Membangun ekuitas merek merupakan bagian terpenting dalam branding suatu produk. Ekuitas Merek didefinisikan sebagai penambahan utilitas atau nilai oleh merek kepada sebuah produk. (Moradi dan Zarei, 2011).

Beberapa peneliti seperti Myers (2003); Prasad dan Dev (2000); De Chernaony (2004) dalam Moradi dan Zarei (2011) menunjukkan bahwa ekuitas yang tinggi menuntun pada preferensi dan loyalitas konsumen terhadap merek. Oleh karena itu preferensi konsumen terhadap merek suatu produk juga berpengaruh terhadap minat pembeliannya pada produk tersebut.

Keller (2003) dalam Moradi dan Zarei (2011) juga menyatakan bahwa disamping perusahaan yang berperan sebagai produsen sebuah produk tertentu, negara asal atau lokasi geografis dari produsen juga memiliki hubungan dengan merek dan juga ikut memberikan 
pengaruh sekunder. Citra Negara Asal dapat berperan sebagai variabel moderasi yang berpengaruh pada sebuah preferensi dan ekuitas merek.

Salah satu jenis produk global yang sangat dibutuhkan dalam beraktivitas terutama bagi kalangan pelajar, mahasiswa dan akademisi adalah produk komputer jinjing atau dikenal dengan laptop. Sebuah penelitian yang dikembangkan oleh Awwad dan Ayesh (2013) menyatakan bahwa laptop telah menjadi perangkat standard yang digunakan oleh kebanyakan mahasiswa. Ia menambahkan bahkan di beberapa universitas di seluruh dunia mewajibkan mahasiswa strata satunya (undergraduate) untuk melengkapi pembelajarannya dengan perangkat laptop. Fitch (2004) dan Stephen (2005) dalam Awwad dan Ayesh (2013) juga menyatakan bahwa laptop meningkatkan partisipasi mahasiswa dalam kelas dan mendorong pembelajaran yang aktif.

Disamping itu, menurut Jaafar et al (2013) keadaan ekonomi, ketidakseimbangan level pemasukan dan naiknya biaya hidup, membuat konsumen mulai merubah kebiasaan mereka dan menjadi lebih sensitif terhadap harga barang. Oleh karena itu, faktor internal (harga barang) juga ikut disertakan dalam penelitian ini sebagai faktor yang berpengaruh pada konsumen dalam merencanakan pembelian produk laptop tersebut.

Meninjau dari permasalahan di atas, Batam sebagai kota urban tentu memiliki pola perilaku masyarakat yang heterogen sehingga hal inilah yang kemudian melatarbelakangi dilakukannya penelitian ini dengan judul Analisis Pengaruh Ekuitas Merek, Preferensi Merek, dan Harga dengan Citra Negara Asal Sebagai Variabel Moderasi terhadap Minat Pembelian Laptop Oleh Mahasiswa di Kota Batam.

\section{Landasan Teori Dan Perumusan Hipotesis}

\section{Minat Pembelian (Purchase Intention)}

Refzani (2012) berpendapat bahwa minat pembelian adalah kecenderungan aksi personal terhadap sebuah merek. Ia juga berpendapat bahwa minat pembelian adalah kesadaran individual untuk berusaha melakukan pembelian terhadap sebuah produk. Roozy (2014) memiliki pendapat bahwa minat pembelian adalah kriteria kriteria sikap yang mengindikasikan keinginan untuk membeli. Roozy (2014) menjelaskan konsep minat pembelian dalam beberapa aspek yaitu willing purchase (keinginan pembelian), considering purchase (pertimbangan pembelian) dan recommendation purchase (saran pembelian).

Wang (2015) berpendapat bahwa minat pembelian adalah kecenderungan konsumen untuk membeli sebuah produk tertentu. Semakin besar keinginan untuk membeli sebuah produk berarti kemungkinannya untuk membeli produk tersebut juga besar. Sebaliknya, sebuah keinginan yang rendah tidak berarti sebuah ketidakmungkinan yang absolut untuk membeli. Vinh (2016) menjelaskan bahwa minat pembelian adalah sebuah kecenderungan subjektif terhadap sebuah produk dan dapat menjadi petunjuk yang penting untuk memprediksikan perilaku konsumen. Vinh (2016) menambahkan bahwa minat pembelian merujuk pada kemampuan konsumen untuk melakukan pembelian kembali sebuah merek di masa yang akan datang.

\section{Ekuitas Merek (Brand Equity) terhadap Minat Pembelian (Purchase Intention)}

Ekuitas Merek didefinisikan sebagai pengaruh pembeda dari pengetahuan sebuah merek pada respon konsumen terhadap pemasaran merek (Mahfooz, 2015). Ia juga menegaskan bahwa ekuitas merek berpengaruh terhadap preferensi merek dan minat pembelian secara langsung dan akhirnya mempengaruhi pilihan merek konsumen. Bukti empiris mengindikasikan bahwa ekuitas merek dapat berpengaruh pada minat pembelian di berbagai 
macam konteks (Jalilvand et al, 2011). Salah satu dimensi ekuitas merek, brand awareness berperan penting dalam pembuatan keputusan konsumen dengan membawa tiga kelebihan, yaitu pembelajaran, pertimbangan, dan pilihan.

Penelitian yang dikembangkan oleh Amran et al (2015) membuktikan bahwasanya ekuitas merek berpengaruh signifikan terhadap minat pembelian. Hal ini membuktikan bahwa ekuitas merek dapat menjelaskan adanya peningkatan pada minat pembelian konsumen. Sebuah penelitian yang dikembangkan oleh Irshad (2012) juga membuktikan hipotesis bahwa ekuitas merek berpengaruh positif dan signifikan pada minat pembelian. Signifikansi tersebut menurut Irshad (2012) disebabkan karena adanya lebih dari satu faktor pendukung pada variabel ekuitas merek. Shahrokh dan Azodi (2013) dalam penelitian yang dikembangkannya menjelaskan bahwa ekuitas merek memiliki pengaruh yang signifikan pada minat pembelian. Dari keseluruhan elemen ekuitas merek, faktor loyalitas merek yang kontribusi paling besar pada pengembangan minat pembelian.

$\mathrm{H}_{1}$ : Ekuitas merek (Brand Equity) memiliki pengaruh positif secara signifikan terhadap minat pembelian (Purchase Intention).

\section{Preferensi Merek (Brand Preference) terhadap Minat Pembelian (Purchase Intention)}

Wang (2015) menjelaskan konsep preferensi merek sebagai sebuah sikap yang mempengaruhi keputusan pembelian seorang konsumen, yang mana akan menghasilkan sebuah perilaku kecenderungan apakah seorang konsumen akan memilih sebuah merek tertentu dan tidak mengindahkan merek lain.

Wang (2015) dalam jurnal yang dikembangkannya menunjukkan bahwa preferensi merek memiliki pengaruh positif yang signifikan terhadap minat pembelian. Para pakar seperti Myers (2003); Prasad dan Dev (2000); De Chernaony (2004) dalam Moradi dan Zarei (2011) menyimpulkan bahwa ekuitas merek yang tinggi mengarah pada preferensi merek dan loyalitas yang tinggi. Seperti halnya ekuitas merek direfleksikan pada preferensi merek, dapat disimpulkan bahwa preferensi merek direfleksikan pada minat pembelian. (Moradi dan Zarei, 2011)

Penelitian yang dikembangkan oleh Buil et al. (2013) menyimpulkan bahwa preferensi merek bertindak sebagai faktor penyebab yang berpengaruh secara positif pada minat pembelian. Moradi dan Zarei (2011) melakukan uji hipotesis dalam penelitian yang dikembangkannya dan menyimpulkan bahwa preferensi merek secara signifikan berpengaruh positif pada minat pembelian. Penelitian serupa dilakukan juga oleh Mahfooz (2015) dan menyimpulkan bahwa preferensi merek merupakan variabel yang berpengaruh secara positif terhadap minat pembelian.

$\mathrm{H}_{2}$ : Preferensi merek (Brand Preference) memiliki pengaruh positif secara signifikan terhadap minat pembelian (Purchase Intention).

\section{Harga (Price) terhadap (Purchase Intention)}

Harga (price) didefinisikan sebagai jumlah uang yang dikeluarkan untuk penggunaan sebuah barang atau jasa atau jumlah nilai yang harus ditukarkan oleh konsumen dengan manfaat yang diperoleh dari penggunaan sebuah produk atau jasa (Jaafar, 2013). Penelitian terdahulu oleh Grunert (2004) menyatakan bahwa minat pembelian konsumen dipengaruhi oleh faktor keuangan. (Jaafar, 2013). Selain itu, Munusamy dan Wong (2008) dalam Jaafar (2013) membuktikan bahwa ada hubungan positif yang signifikan antara harga dan motif konsumen terhadap pembelian produk. Oleh karena itu, sebagian besar konsumen akan 
membuat keputusan mereka dengan mengacu pada produk dengan harga rendah (Jaafar, 2013). Ray dan Ray (2011) menyatakan bahwa produk yang diperkenalkan ke pasar haruslah memenuhi ekspektasi konsumen yang menjadi targetnya. Soon, de Run, \& Hong (2013) menyatakan bahwa harga penjualan selalu menjadi pertimbangan utama untuk membeli (Seng dan Husin, 2015).

$\mathrm{H}_{3}$ : Harga (Price) memiliki pengaruh positif secara signifikan terhadap minat pembelian (Purchase Intention).

\section{Pengaruh Moderasi Citra Negara Asal (Country of Origin)}

Yasin (2015) menyimpulkan citra negara asal sebagai persepsi secara umum dari konsumen tentang kualitas produk yang dibuat di sebuah negara tertentu. Saydan (2013) mengatakan bahwa variabel negara asal adalah salah satu variabel penting lainnya yang mempengaruhi persepsi konsumen terhadap sebuah merek. Moradi dan Zarei (2011) juga mengatakan bahwa variabel negara asal dapat bertindak sebagai variabel moderasi yang juga berpengaruh pada preferensi merek.

Sanyal dan Datta (2011) dalam Saydan (2013) melakukan analisis pada hubungan antara citra negara asal dan komponen komponen ekuitas merek. Disimpulkan bahwa brand strength dan brand awareness menuntun pada pembentukan citra negara asal yang kuat. (Saydan, 2013).

$\mathrm{H}_{4}$ : Ekuitas merek (Brand Equity) memiliki pengaruh positif secara signifikan terhadap minat pembelian (Purchase Intention) dengan citra negara asal (Country of Origin Image) sebagai variabel moderasi.

Studi konseptual yang dikembangkan oleh Rezfani et al. (2012) menyatakan bahwa negara asal dapat memberikan dampak positif ataupun negatif pada minat pembelian konsumen. Studi literatur lain yang dikembangkan oleh Yasin (2015) menyimpulkan bahwa para marketer dan peneliti perilaku konsumen secara umum dapat menerima bahwa citra negara asal dari sebuah produk atau merek adalah sebuah faktor penting dalam pembuatan keputusan konsumen. Yasin (2015) menambahkan juga bahwa evaluasi menyeluruh dari sebuah produk dipengaruhi oleh country stereotype (penilaian kebanyakan orang tentang sebuah negara). Dengan demikian gambaran yang dimiliki konsumen tentang sebuah negara akan mempengaruhi persepsinya terhadap produk produk yang berasal dari negara tersebut. Sebagaimana persepsi konsumen terhadap suatu negara asal produk tertentu berpengaruh pada evaluasi konsumen akan sebuah produk, maka hal ini juga akan mempengaruhi preferensi, minat pembelian dan pilihan mereka atas merek tertentu (Yasin, 2015)

$\mathrm{H}_{5}$ : Preferensi merek (Brand Preference) memiliki pengaruh positif secara signifikan terhadap minat pembelian (Purchase Intention) dengan citra negara asal (Country of Origin Image) sebagai variabel moderasi.

\section{Metode Penelitian}

Objek pada penelitian ini adalah para mahasiswa Kota Batam yang mengenal produk laptop. Mahasiswa dipilih menjadi objek penelitian karena merupakan populasi yang sangat potensial dalam penggunaan produk laptop. Darakhsan dan Islam (2014) mengatakan bahwa kemajuan dalam teknologi yang telah merubah pandangan dalam mendapatkan dan memberikan kualitas pendidikan, membuat penggunaan laptop dan perangkat digital lainnya adalah bagian terintegrasi dari perangkat pembelajaran mahasiswa. Adapun pemilihan merek 
laptop yang akan digunakan dalam penelitian ini didasarkan pada Top Brand Award 2016 yaitu Acer, Asus, Lenovo, Toshiba, HP, Samsung dan Apple.

Populasi yang digunakan dalam penelitian ini adalah seluruh mahasiswa yang berkuliah di Kota Batam. Berdasarkan data dari Pangkalan Data Pendidikan Tinggi Kementrian Riset, Teknologi dan Pendidikan Tinggi diketahui jumlah mahasiswa di Kota Batam adalah 26.033 mahasiswa.

Penarikan sampel yang dilakukan dalam penelitian ini, menggunakan metode judgmental sampling yaitu teknik penentuan sampling dengan pertimbangan tertentu. Teknik penentuan jumlah responden yang representatif dari keseluruhan populasi populasi yang ada menggunakan rumus yang dikembangkan oleh Sukandarrumidi (2008). Maka dari jumlah populasi sebesar 26.033 mahasiswa, jumlah sampel minimal yang harus diambil adalah 394 sampel. Peneliti menambah jumlah responden hingga 500 sampel untuk menghindari resiko kuesioner yang tidak kembali, tidak sah dan pengurangan data responden pada pengujian outlier.

Sampel penelitian yang diambil dari penelitian ini adalah mahasiswa dari 5 universitas dengan jumlah mahasiswa tertinggi di Kota Batam, yaitu Universitas Putera Batam, Universitas Riau Kepulauan, Politeknik Negeri Batam, Universitas Internasional Batam, dan Universitas Batam.

Tabel 1 di bawah ini adalah daftar pertanyaan dari variabel operasional yang digunakan dalam penelitian

Tabel 1. Daftar Pertanyaan Penelitian

\begin{tabular}{|c|c|c|c|}
\hline No & Jenis Variabel & Jumlah Pertanyaan & $\begin{array}{c}\text { Sumber dan Skala yang } \\
\text { Digunakan }\end{array}$ \\
\hline 1 & $\begin{array}{l}\text { Citra Negara } \\
\text { Asal } \\
\text { (Moderasi) }\end{array}$ & $\begin{array}{l}\text { - Negara tempat merek laptop yang } \\
\text { saya gunakan berasal adalah negara } \\
\text { yang inovatif dalam pembuatan } \\
\text { laptop } \\
\text { - Negara tempat merek laptop yang } \\
\text { saya gunakan berasal adalah negara } \\
\text { yang memiliki kemajuan teknologi } \\
\text { yang tinggi } \\
\text { - Negara tempat merek laptop yang } \\
\text { saya gunakan berasal adalah negara } \\
\text { yang bagus dalam hal desain } \\
\text { - Negara tempat merek laptop yang } \\
\text { saya gunakan berasal adalah negara } \\
\text { yang kreatif dalam kecakapan } \\
\text { kerjanya } \\
\text { - Negara tempat merek laptop yang } \\
\text { saya gunakan berasal adalah negara } \\
\text { yang memiliki kualitas tinggi } \\
\text { dalam kecakapan kerjanya } \\
\text { - Negara tempat merek laptop yang } \\
\text { saya gunakan berasal adalah negara } \\
\text { yang bergengsi } \\
\text { - Negara tempat merek laptop yang } \\
\text { saya gunakan berasal adalah negara } \\
\text { yang memiliki citra sebagai negara } \\
\text { maju }\end{array}$ & $\begin{array}{l}\text { - } \text { Yasin (2015), } 7 \text { item } \\
\text { - Lima poin skala Likert (1 } \\
\text { adalah sangat tidak } \\
\text { setuju), } 2 \text { adalah tidak } \\
\text { setuju, } 3 \text { adalah netral, } 4 \\
\text { adalah setuju dan } 5 \text { adalah } \\
\text { sangat setuju). }\end{array}$ \\
\hline
\end{tabular}




\begin{tabular}{|c|c|c|c|}
\hline 2 & $\begin{array}{l}\text { Ekuitas Merek } \\
\text { (Independen) }\end{array}$ & $\begin{array}{l}\text { - Meskipun jika merek lain memiliki } \\
\text { fitur yang sama dengan merek } \\
\text { laptop yang saya gunakan, saya } \\
\text { tetap akan memilih merek saya } \\
\text { - Jika saya harus memilih merek } \\
\text { laptop, merek sayalah yang pasti } \\
\text { saya pilih } \\
\text { - Jika saya harus membeli laptop, } \\
\text { saya akan berencana untuk } \\
\text { menggunakan merek saya } \\
\text { meskipun terdapat merek lain yang } \\
\text { sama baiknya laptop lain } \\
\text { - Meskipun merek lan } \\
\text { memiliki harga yang yang sama } \\
\text { dengan merek saya, saya tetap } \\
\text { memilih merek saya } \\
\text { - Jika ada merek lain yang sebaik } \\
\text { merek saya, saya lebih memilih } \\
\text { menggunakan merek saya } \\
\text { - Menggunakan merek saya, akan } \\
\text { menambah nilai pada pengalaman } \\
\text { saya }\end{array}$ & $\begin{array}{l}\text { - Mahfooz (2015), } 5 \text { item } \\
\text { - Lima poin skala Likert (1 } \\
\text { adalah sangat tidak } \\
\text { setuju), } 2 \text { adalah tidak } \\
\text { setuju, } 3 \text { adalah netral, } 4 \\
\text { adalah setuju dan } 5 \text { adalah } \\
\text { sangat setuju). }\end{array}$ \\
\hline 3 & $\begin{array}{l}\text { Preferensi } \\
\text { Merek } \\
\text { (Independen) }\end{array}$ & $\begin{array}{l}\text { - Menurut saya, merek laptop saya } \\
\text { lebih baik daripada merek lain } \\
\text { - Saya lebih memilih merek laptop } \\
\text { saya } \\
\text { - Jika saya membeli laptop, saya } \\
\text { akan mempertimbangkan merek } \\
\text { saya terlebih dahulu }\end{array}$ & $\begin{array}{l}\text { - Mahfooz (2015), } 3 \text { item } \\
\text { - Lima poin skala Likert (1 } \\
\text { adalah sangat tidak } \\
\text { setuju), } 2 \text { adalah tidak } \\
\text { setuju, } 3 \text { adalah netral, } 4 \\
\text { adalah setuju dan } 5 \text { adalah } \\
\text { sangat setuju). }\end{array}$ \\
\hline 4 & $\begin{array}{l}\text { Harga } \\
\text { (Moderasi) }\end{array}$ & $\begin{array}{l}\text { - Menurut saya, faktor harga penting } \\
\text { ketika saya akan membeli laptop } \\
\text { - Saya membandingkan harga antar- } \\
\text { laptop karena saya akan memilih } \\
\text { salah satu } \\
\text { - Menurut saya, harga merek laptop } \\
\text { saya masuk akal bagi para } \\
\text { konsumen } \\
\text { - Harga merek laptop saya lebih } \\
\text { murah daripada harga rata rata } \\
\text { laptop } \\
\text { - Saya menggunakan merek laptop } \\
\text { saya karena lebih murah dari yang } \\
\text { lain }\end{array}$ & $\begin{array}{l}- \text { - Jaafar (2013), } 5 \text { item } \\
\text { - Lima poin skala Likert (1 } \\
\text { adalah sangat tidak } \\
\text { setuju), } 2 \text { adalah tidak } \\
\text { setuju, } 3 \text { adalah netral, } 4 \\
\text { adalah setuju dan } 5 \text { adalah } \\
\text { sangat setuju). }\end{array}$ \\
\hline 5 & $\begin{array}{l}\text { Minat } \\
\text { Pembelian } \\
\text { (Dependen) }\end{array}$ & $\begin{array}{l}\text { - Saya membeli merek laptop saya } \\
\text { untuk menghemat pengeluaran } \\
\text { - Saya akan mempertimbangkan } \\
\text { untuk membeli laptop saya } \\
\text { - Saya akan membeli merek laptop } \\
\text { saya }\end{array}$ & $\begin{array}{l}- \text { Jaafar (2013), } 3 \text { item } \\
\text { - Lima poin skala Likert }(1 \\
\text { adalah sangat tidak } \\
\text { setuju), } 2 \text { adalah tidak } \\
\text { setuju, } 3 \text { adalah netral, } 4 \\
\text { adalah setuju dan } 5 \text { adalah } \\
\text { sangat setuju). }\end{array}$ \\
\hline
\end{tabular}




\section{Metode Analisis Data}

\section{Uji Outlier}

Outlier adalah sebuah observasi yang berada diluar keseluruhan pola observasi yang lain (Hair et al. 2009). Uji outlier ini bertujuan untuk menemukan data data yag secara jelas berbeda bila dibandingkan dengan data data lainnya. Untuk menguji apakah data yang diperoleh terdapat data yang menyimpang (outlier), maka dapat dilakukan dengan cara melihat nilai SDR (Studentized Deleted Residual). Berdasarkan tabel t yang dikemukakan oleh Pearson dan Hartley (1966), jika jumlah sampel melebihi 120 responden, maka nilai SDR yang terkena outlier adalah $>1,96$ atau $<-1,96$.

\section{Uji Kualitas Data}

\section{Uji Validitas}

Uji validitas digunakan untuk mengukur valid atau tidaknya suatu kuesioner. Suatu kuesioner dikatakan valid jika pertanyaan pada kuesioner mampu mengungkapkan sesuatu yang akan diukur oleh kuesioner tersebut (Hair et al, 2010). Validasi yang dilihat pada penelitian ini adalah besar korelasi antara masing masing item pertanyaan terhadap total skornya. Jika nilai korelasi $>0,3$ maka dapat dikatakan bahwa item pertanyaan yang diukur adalah valid

\section{Uji Reliabilitas}

Uji reliabilitas adalah alat untuk mengukur suatu kuesioner yang merupakan indikator dari variabel atau konstruk. Kuesioner dapat dikatakan reliabel jika jawaban seseorang terhadap pernyataan adalah konsisten atau stabil dari waktu ke waktu. Suatu skala dianggap reliable yaitu dapat dipercaya, bila secara konsisten memberikan hasil yang sama jika diterapkan pada sampel yang sama pada waktu yang berbeda (Nasution, 2003). Pengujian reliabilitas menggunakan metode statistik Cronbach Alpha. Nilai Cronbach Alpha yang menunjukkan pertanyaan pada kuesioner dapat diterima (acceptable) yang bernilai > 0,6 (Ghozali, 2006).

\section{Uji Asumsi Klasik}

\section{Uji Normalitas}

Uji normalitas bertujuan untuk menguji apakah dalam model regresi variabel independen dan variabel dependen memiliki distribusi normal atau tidak dan menggunakan Uji Kolmogorov Smirnov sebagai pedoman. Model regresi yang baik adalah memiliki distribusi data yang normal atau mendekati normal (Ghozali, 2011). Data disimpulkan tersebar normal jika nilai signifikansi pada Kolmogorov Smirnov adalah > 0,05.

\section{Uji Multikolinieritas}

Uji multikolinieritas bertujuan untuk menguji apakah dalam sebuah model regresi ditemukan adanya korelasi antar variabel independen. Jika terjadi korelasi, maka dinamakan terdapat problem multikolinieritas. Model regeresi yang baik seharusnya tidak terjadi korelasi anta variabel independen. Suatu model regresi yang bebas multikolinieritas apabila memiliki nilai VIF (Variance Inflation Factor) di bawah angka 10 dan mempunyai tolerance $>0.10$ (Ghozali, 2006). 


\section{Uji Heteroskedastisitas}

Uji heteroskedastisitas yaitu untuk mengetahui ada atau tidaknya ketidaksamaan varian dari residual pada sebuah model regresi. Jika varian tetap maka disebut homoskedastisitas, dan jika berbeda maka terjadi masalah hetroskedastisitas. Model regresi yang baik adalah model regresi yang tidak terjadi hetroskedastisitas. Gujarati (2013) menyatakan uji heteroskedastisitas secara empiris dapat dilakukan dengan uji glejser, yaitu dengan meregresikan nilai absolut residual dengan variabel independen dalam model. Jika nilai signifikansi antara variabel independen dengan absolut residual lebih dari 0,05 maka tidak terjadi masalah heteroskedastisitas, sedangkan variabel independen dengan absolut residual kurang dari 0,05 maka terjadi masalah heteroskedastisitas. Model regresi yang baik adalah yang homoskedastisitas atau tidak terjadi heteroskedastisitas.

\section{Uji Hipotesis}

\section{Uji F}

Uji F digunakan untuk untuk menunjukkan apakah seluruh variabel independen secara simultan berpengaruh terhadap variabel dependen. Cara uji $\mathrm{F}$ adalah dengan melihat hasil signifikan dimana probabilitas $<0,05$ maka hasil dari pengujian berpengaruh terhadap variabel dependen, jika probabilitas $>0,05$ maka hasil dari pengujiain tidak berpengaruh signifikan terhadap variabel dependen (Ghozali, 2011).

\section{Uji T}

Uji T digunakan untuk untuk menunjukkan seberapa jauh variabel independen secara individual berpengaruh terhadap variabel dependen. Cara uji $\mathrm{T}$ adalah dengan melihat hasil signifikan dimana probabilitas $<0,05$ berarti hasil dari pengujian adalah signifikan dan probabilitas $>0,05$ berarti hasil dari pengujian adalah tidak signifikan (Ghozali, 2011).

\section{Uji Koefisien Determinasi $\left(\mathbf{R}^{2}\right)$}

Uji $R^{2}$ pada prinsipnya mengukur sejauh mana kemampuan model menerangkan variasi variabel dependen. Nilai koefesien determinasi adalah antara nol (0) dan satu (1). Jika nilai $\mathrm{R}^{2}$ kecil artinya kemampuan variabel independen sangat terbatas. Jika nilai $\mathrm{R}^{2}$ mendekati satu (1) berarti variabel independen dapat memberikan hampir keseluruhan informasi yang dibutuhkan untuk memprediksi variabel dependen (Ghozali, 2006).

$R$ Square $\left(\mathrm{R}^{2}\right)$ pada persamaan regresi rentan terhadap penambahan variabel independent, dimana semakin banyak variabel independen yang terlibat, maka nilai $\mathrm{R}^{2}$ akan semakin besar. Oleh karena itulah pada penelitian yang menggunakan analisis regresi linier berganda ini, digunakan adjusted $R$ square. Dalam penelitian ini, pengolahan data menggunakan aplikasi IBM SPSS Statistics 21.

\section{Uji Moderasi}

Variabel moderasi adalah variabel yang variasi nilainya mempunyai pengaruh ketergantungan yang kuat terhadap pengaruh atau hubungan antara variabel independen dengan variabel dependen (Mustafa, 2009). Pada penelitian ini, metode yang digunakan untuk uji moderasi adalah Multiple Regression Analysis. Metode ini dilakukan dengan menambahkan variabel independen dengan variabel moderasinya. Hipotesis diterima jika interaksi variabel independen dengan variabel moderasi mempunyai pengaruh signifikan terhadap variabel dependen. 


\section{Analisis Dan Pembahasan}

\section{Uji Outlier}

Jumlah data responden yang digunakan untuk uji outlier adalah sebanyak 439 data. Pengujian tersebut menggunakan metode SDR. Setelah dilakukan pengujian data outlier sebanyak 2 kali, tersisa data sebanyak 403 data yang akan digunakan untuk analisis selanjutnya.

\section{Hasil Uji Kualitas Data}

Uji validitas dilakukan terhadap 7 item pertanyaaN dari variabel country of origin. 5 pertanyaan dari variabel brand equity, 3 pertanyaan dari variabel brand preference, 5 pertanyaan dari variabel price, dan 3 pertanyaan dari variabel purchase intention. Seluruh item pertanyaan dikatakan valid dan dapat dilanjutkan pada analisis selanjutnya. Dari uji reabilitas dapat di simpulkan bahwa seluruh variabel realiabel karena hasilnya Cronbach's Alpha di atas 0,6

\section{Uji Hipotesis}

\section{Uji F}

Uji $F$ dalam regresi linier berganda digunakan untuk menguji pengaruh variabel independen terhadap dependen secara simultan. Cara uji $\mathrm{F}$ adalah dengan melihat apabila tingkat signifikan >0,05, maka variabel independen secara simultan tidak berpengaruh signifikan terhadap variabel dependen. Sebaliknya, jika tingkat signifikan $<0,05$ maka variabel independen secara simultan berpengaruh signifikan terhadap variabel dependen (Ghozali, 2002). Hasil uji F pada Tabel dibawah ini menunjukkan tingkat signifikansi sebesar 0,000 . Hal ini berarti bahwa variabel independen secara simultan berpengaruh signifikan terhadap variabel dependen

Tabel 2. Hasil Uji F Variabel Brand Equity, Brand Preference dan Price terhadap Purchase Intention

\begin{tabular}{ccrc}
\hline Variabel Dependen & Nilai F & Signifikansi & \multicolumn{1}{c}{ Kesimpulan } \\
\hline Purchase Intention & 69,710 & 0,000 & Signifikan \\
\hline
\end{tabular}

Sumber: Data primer diolah (2017).

\section{Hasil Uji T}

Cara uji $\mathrm{t}$ adalah dengan melihat apabila tingkat signifikan $>0,05$ maka variabel independen tidak terdapat pengaruh yang signifikan terhadap variabel dependen. Sebaliknya, jika tingkat signifikan $<0,05$ maka independen terdapat pengaruh yang signifikan terhadap variabel dependen (Ghozali, 2005).

Tabel 3. Hasil Uji T Variabel Brand Equity, Brand Preference dan Price terhadap Purchase Intention

\begin{tabular}{lccccc}
\hline \multicolumn{1}{c}{ Model } & $\begin{array}{c}\text { Unstandardized } \\
\text { Coefficients } \\
\boldsymbol{B}\end{array}$ & $\boldsymbol{T}$ & Sig. & Kesimpulan & Hipotesis \\
\hline (Constant) & 5,602 & 13,307 & 0,000 & & \\
Brand Equity & 0,119 & 6,556 & 0,000 & Signifikan positif & H1 \\
Brand Preference & 0,113 & 3,557 & 0,000 & Signifikan positif & H2 \\
Price & 0,098 & 4,120 & 0,000 & Signifikan positif & H3 \\
\hline
\end{tabular}

Variabel Dependen : Purchase Intention

Sumber: Data primer diolah (2017). 
Berdasarkan tabel di atas, dapat diketahui bahwa seluruh variabel independen memiliki nilai signifikansi sebesar 0,000. Hal tersebut menunjukkan bahwa masing masing variabel yaitu Brand Equity, Brand Preference dan Price memiliki pengaruh signifikan terhadap variabel dependen.

\section{H1 Ekuitas merek (Brand Equity) memiliki pengaruh positif secara signifikan terhadap minat pembelian (Purchase Intention).}

Berdasarkan hasil uji pada tabel 4.19, variabel ekuitas merek memiliki perhitungan signifikansinya 0,000 atau $<0,05$. Nilai tersebut menunjukkan bahwa variabel ekuitas merek memiliki pengaruh secara signifikan terhadap minat pembelian. Dengan demikian pengujian H1 bahwa ekuitas merek (Brand Equity) memiliki pengaruh positif secara signifikan terhadap minat pembelian (Purchase Intention) diterima.

Ekuitas merek memiliki pengaruh yang signifikan terhadap minat pembelian karena variabel ini menentukan keinginan konsumen untuk tetap menggunakan sebuah merek atau berhenti menggunakannya (Keller, 1993) dalam (Amran et al, 2015). Hasil uji ini sesuai dengan pendapat yang dikemukakan oleh Jalilvand et al (2011), Irshad (2012), Choe dan Zhao (2013), Shahrokh dan Azodi (2013), Amran et al (2015), dan Mahfooz (2015) dalam penelitian yang mereka kembangkan.

\section{H2. Preferensi merek (Brand Preference) memiliki pengaruh positif secara signifikan terhadap minat pembelian (Purchase Intention).}

Berdasarkan hasil uji pada tabel 4.19, variabel preferensi merek memiliki nilai perhitungan signifikansinya 0,000 atau $<0,05$. Nilai tersebut menunjukkan bahwa variabel preferensi merek memiliki pengaruh secara signifikan terhadap minat pembelian. Dengan demikian pengujian $\mathrm{H} 2$ bahwa preferensi merek (Brand Preference) memiliki pengaruh positif secara signifikan terhadap minat pembelian (Purchase Intention) diterima.

Variabel preferensi merek berpengaruh positif secara signifikan terhadap minat pembelian yang berarti bahwa konsumen yang memprioritaskan pembelian pada merek produk yang menjadi pilihan utamanya dibandingkan dengan merek lain. Preferensi merek seorang konsumen terhadap sebuah produk mempengaruhi keputusan pembeliannya, yang mana akan menghasilkan sebuah perilaku kecenderungan apakah seorang konsumen akan memilih sebuah merek tertentu dan tidak mengindahkan merek lain. (Wang, 2015)

Hasil uji ini sesuai dengan pendapat yang dikemukakan oleh Myers (2003); Prasad dan Dev (2000); De Chernaony (2004) dalam Moradi dan Zarei (2011), Buil et al. (2013), Wang (2015), Mahfooz (2015), Amran et al (2015). Penelitian yang mereka kembangkan menyimpulkan bahwa variabel preferensi merek berpengaruh positif secara signifikan terhadap variabel minat pembelian.

\section{H3. Harga (Price) memiliki pengaruh positif secara signifikan terhadap minat pembelian (Purchase Intention).}

Berdasarkan hasil uji pada tabel 4.19, variabel price memiliki nilai perhitungan signifikansi sebesar 0,000 atau $<0,05$. Nilai tersebut menunjukkan bahwa variabel harga (price) memiliki pengaruh secara signifikan terhadap minat pembelian. Dengan demikian pengujian $\mathrm{H} 3$ bahwa harga (price) memiliki pengaruh positif secara signifikan terhadap minat pembelian (purchase intention) diterima.

Pengaruh signifikan pada variabel harga ini adalah karena harga selalu menjadi pertimbangan utama dalam melakukan pembelian (Seng \& Husin, 2015). Hasil uji ini sesuai dengan penelitian yang dikembangkan oleh Ray dan Ray (2011), Jaafar (2013), Bilal dan Ali 
(2013), Tih dan Lee (2013), Chou (2013) Soon, de Run, \& Hong (2013), Cheng dan Cheng (2013), Darakhsan dan Islam (2014), Seng \& Husin, (2015) dan Mirabi et al (2015)

\section{Hasil Uji Koefisien Determinasi}

Uji koefisien determinasi digunakan untuk mengukur sejauh mana kemampuan model dalam menerangkan variasi variabel dependen. Nilai koefisien determinasi berada antara 0 dan 1. Jika nilai $\mathrm{R}^{2}$ kecil artinya kemampuan variabel independen untuk menjelaskan variasi variabel dependen sangat terbatas. Sedangkan jika nilai $\mathrm{R}^{2}$ mendekati satu, maka variabel independen dapat memberikan hampir seluruh informasi yang dibutuhkan untuk memprediksi variasi variabel dependen (Wibowo, 2012).

Tabel 4. Hasil Uji Koefisien Determinasi

\begin{tabular}{ccccc}
\hline Model & $\boldsymbol{R}$ & $\boldsymbol{R}$ Square & $\begin{array}{c}\text { Adjusted } \boldsymbol{R} \\
\text { Square }\end{array}$ & $\begin{array}{c}\text { Std. Error of the } \\
\text { Estimate }\end{array}$ \\
\hline 1 & $0,586^{\mathrm{a}}$ & 0,344 & 0,339 & 1,23210 \\
\hline
\end{tabular}

Variabel Independen : Ekuitas Merek, Preferensi Merek, Harga

Variabel Dependen : Minat Pembelian

Sumber: Data primer diolah (2017)

Berdasarkan hasil uji koefisien determinasi di atas diperoleh nilai adjusted $R^{2}$ sebesar 0,339 berarti 33,9\% variabel purchase intention dijelaskan oleh brand equity, brand preference, dan price sebagai variabel independen dengan moderasi country of origin image. Sedangkan sisanya $66,1 \%$ dijelaskan oleh sebab sebab lain diluar model. Sedangkan nilai Standard Error of The Estimate sebesar 1,23210 berarti tingkat kesalahan penafsiran adalah sebesar 1,23.

H4. Ekuitas merek (Brand Equity) memiliki pengaruh positif secara signifikan terhadap minat pembelian (Purchase Intention) dengan citra negara asal (Country of Origin Image) sebagai variabel moderasi.

Untuk melakukan pengujian pengaruh variabel citra negara asal sebagai variabel moderasi yang memperkuat hubungan antara variabel ekuitas merek dan minat pembelian, dilakukan analisis regresi yang melibatkan variabel moderasi citra negara asal pada variabel independen. Hipotesis diterima jika interaksi variabel independen dengan variabel moderasi mempunyai pengaruh signifikan terhadap variabel dependen.

Tabel 5. Hasil Uji Moderasi

\begin{tabular}{|c|c|c|c|c|c|c|}
\hline & \multirow{2}{*}{ Model } & \multicolumn{2}{|c|}{$\begin{array}{l}\text { Unstandardized } \\
\text { Coefficient }\end{array}$} & \multirow{2}{*}{$\mathbf{T}$} & \multirow{2}{*}{ Sig } & \multirow{2}{*}{ Kesimpulan } \\
\hline & & B & $\begin{array}{l}\text { Std. } \\
\text { Error }\end{array}$ & & & \\
\hline \multirow{2}{*}{1} & (Constant) & 7,375 & 0,317 & 23,261 & 0,000 & Signifikan \\
\hline & Brand Equity & 0,186 & 0,015 & 12,476 & 0,000 & Signifikan \\
\hline \multirow{3}{*}{2} & (Constant) & 6,905 & 0,436 & 15,822 & 0,000 & Signifikan \\
\hline & Brand Equity & 0,179 & 0,016 & 11,564 & 0,000 & Signifikan \\
\hline & Country of Origin & 0,024 & 0,015 & 1,563 & 0,119 & Tidak Signifikan \\
\hline \multirow{4}{*}{3} & (Constant) & 9,036 & 1,781 & 5,074 & 0,000 & Signifikan \\
\hline & Brand Equity & 0,077 & 0,084 & 0,912 & 0,362 & Tidak Signifikan \\
\hline & Country of Origin & $-0,058$ & 0,068 & $-0,858$ & 0,392 & Tidak Signifikan \\
\hline & Moderating COO_BE & 0,004 & 0,003 & 1,234 & 0,218 & Tidak Signifikan \\
\hline
\end{tabular}

Variabel Dependen : Purchase Intention

Sumber : Data sekunder yang diolah (2017) 
Dari tabel di atas dapat diketahui pengaruh masing-masing variabel secara parsial. Pada model 1 brand equity menjadi satu-satunya variabel independen yang signifikan mempengaruhi purchase intention. Pada model 2, terlihat bahwa terjadi penurunan tingkat signifikansi jika variabel country of origin menjadi variabel independen. Kemudian pada model 3 variabel brand equity dan country of origini tidak berpengaruh signifikan terhadap purchase intention begitupun juga interaksi antara kedua variabel tersebut tidak menunjukkan signifikansi pengaruh terhadap purchase intention. Dengan demikian dapat disimpulkan bahwa country of origin tidak memoderasi pengaruh antara brand equity dan purchase intention. Oleh karena itu, $\mathrm{H} 4$ yang menyatakan bahwa ekuitas merek (brand equity) memiliki pengaruh positif secara signifikan terhadap minat pembelian (purchase intention) dengan citra negara asal (country of origin image) sebagai variabel moderasi ditolak. Hasil ini bertolak belakang dari hasil penelitan yang dikembangkan oleh Wang et al (2008) dan Chung et al (2009) dalam Moradi dan Zarei (2011) dan Saydan (2013).

H5. Preferensi merek (Brand Preference) memiliki pengaruh positif secara signifikan terhadap minat pembelian (Purchase Intention) dengan citra negara asal (Country of Origin Image) sebagai variabel moderasi.

Untuk melakukan pengujian pengaruh variabel citra negara asal sebagai variabel moderasi yang memperkuat hubungan antara variabel preferensi merek dan minat pembelian, dilakukan analisis regresi yang melibatkan variabel moderasi citra negara asal pada variabel independen. Hipotesis diterima jika interaksi variabel independen dengan variabel moderasi mempunyai pengaruh signifikan terhadap variabel dependen

Tabel 6. Hasil Uji Moderasi

\begin{tabular}{|c|c|c|c|c|c|c|}
\hline & \multirow{2}{*}{ Model } & \multicolumn{2}{|c|}{$\begin{array}{l}\text { Unstandardized } \\
\text { Coefficient }\end{array}$} & \multirow{2}{*}{$\mathbf{T}$} & \multirow{2}{*}{ Sig } & \multirow{2}{*}{ Kesimpulan } \\
\hline & & B & $\begin{array}{l}\text { Std. } \\
\text { Error }\end{array}$ & & & \\
\hline \multirow{2}{*}{1} & (Constant) & 7,698 & 0,344 & 22,356 & 0,000 & Signifikan \\
\hline & Brand Preference & 0,336 & 0,032 & 10,512 & 0,000 & Signifikan \\
\hline \multirow{3}{*}{2} & (Constant) & 6,839 & 0,472 & 14,485 & 0,000 & Signifikan \\
\hline & Brand Preference & 0,318 & 0,032 & 9,794 & 0,000 & Signifikan \\
\hline & Country of Origin & 0,040 & 0,015 & 2,636 & 0,009 & Signifikan \\
\hline \multirow{4}{*}{3} & (Constant) & 10,445 & 1,909 & 5,472 & 0,000 & Signifikan \\
\hline & Brand Preference & $-0,015$ & 0,173 & $-0,084$ & 0,933 & Tidak Signifikan \\
\hline & Country of Origin & $-0,103$ & 0,075 & $-1,371$ & 0,171 & Tidak Signifikan \\
\hline & Moderating $C O O \_B P$ & 0,013 & 0,007 & 1,949 & 0,052 & Tidak Signifikan \\
\hline
\end{tabular}

Variabel Dependen : Purchase Intention

Sumber : Data sekunder yang diolah (2017)

Dari tabel di atas dapat diketahui pengaruh masing-masing variabel secara parsial. Pada model 1 brand preference menjadi satu-satunya variabel independen yang signifikan mempengaruhi purchase intention. Pada model 2, terlihat bahwa terjadi penurunan tingkat signifikansi jika variabel country of origin dimasukkan menjadi variabel independen. Kemudian pada model 3 variabel brand preference dan country of origini tidak berpengaruh signifikan terhadap purchase intention begitupun juga interaksi antara kedua variabel tersebut tidak menunjukkan signifikansi pengaruh terhadap purchase intention. Dengan demikian dapat disimpulkan bahwa country of origin tidak memoderasi pengaruh antara brand preference dan purchase intention. Oleh karena itu, H5 yang menyatakan bahwa preferensi 
merek (brand preference) memiliki pengaruh positif secara signifikan terhadap minat pembelian (purchase intention) dengan citra negara asal (country of origin image) sebagai variabel moderasi ditolak. Hasil ini bertolak belakang dari hasil penelitan yang dikembangkan oleh Wang et al (2008) dan Chung et al (2009) dalam Moradi dan Zarei (2011) dan Saydan (2013).

\section{Kesimpulan, Keterbatasan dan Rekomendasi}

\section{Kesimpulan}

Berdasarkan hasil pengolahan data pada bab sebelumnya dapat ditarik kesimpulan sebagai berikut.

a. Variabel ekuitas merek (brand equity) berpengaruh signifikan terhadap minat pembelian (purchase intention). Hal ini sejalan dengan penelitian yang dikembangkan oleh Jalilvand et al (2011), Moradi dan Zarei (2011), Irshad (2012), Shahrokh dan Azodi (2013), Choe dan Zhao (2013), Amran et al (2015), dan Mahfooz (2015)

b. Variabel preferensi merek (brand preference) berpengaruh secara signifikan terhadap minat pembelian (purchase intention). Hal ini sejalan dengan penelitian yang dikembangkan oleh Buil et al (2013), Moradi dan Zarei (2011), Wang (2015), Amran et al (2015) dan Mahfooz (2015).

c. Variabel citra negara asal (country of origin) memperkuat hubungan antara variabel ekuitas merek (brand equity) dan minat pembelian (purchase intention). Hal ini sejalan dengan penelitian yang dikembangkan oleh Moradi dan Zarei (2011) dan Saydan (2013).

d. Variabel citra negara asal (country of origin) memperkuat hubungan antara variabel preferensi merek (brand preference) dan minat pembelian (purchase intention). Hal ini sejalan dengan penelitian yang dikembangkan oleh Moradi dan Zarei (2011).

e. Variabel harga (price) berpengaruh secara signifikan terhadap variabel minat pembelian (purchase intention). Hal ini sejalan dengan penelitian yang dikembangkan oleh Bilal dan Ali (2013), Jaafar et al (2013), Chou (2013), Tih dan Lee (2013), Cheng dan Cheng (2013), Darakhsan dan Islam (2014), Mirabi et al (2015), dan Seng dan Husin (2015)

\section{Rekomendasi}

Penelitian ini membuktikan adanya pengaruh yang sesuai dengan model penelitian. Dengan demikian hal ini dapat menjadi suatu bentuk perhatian bagi manajer pemasaran sebuah perusahaan dalam meningkatkan presentase minat pembelian sebuah produk. Adapun saran yang dapat disampaikan oleh penulis adalah sebagai berikut.

a. Ekuitas merek dan preferensi merek berpengaruh signifikan terhadap minat pembelian. Dengan demikian manajer pemasaran perlu menghubungkan komunikasi antara merek dengan sebuah produk. Merek pada produk hendaknya memiliki sebuah keunggulan kompetitif sehingga dapat meningkatkan loyalitas dan prioritas pelanggan terhadap sebuah merek. Elemen elemen dalam ekuitas merek sebuah produk seperti brand assosiations, brand awareness, perceived quality dan brand loyalty perlu ditingkatkan agar menaikkan presentase minat pembelian pelanggan. Dalam meningkatkan level ekuitas merek pada sebuah produk, manajer pemasaran juga dapat menerapkan metode pemasaran melalui media sosial sebagaimana telah disampaikan pada penelitian terdahulu.

b. Harga berpengaruh signifikan terhadap minat pembelian. Dengan demikian manajer pemasaran dalam menetapkan harga sebuah produk perlu menyesuaikan dengan kemampuan pelanggan dan kesesuaian harga dengan produk yang akan dipasarkan. 
Harga sebuah produk haruslah memenuhi kriteria yang masuk akal bagi para pelanggan. Hal tersebut dikarenakan faktor harga adalah faktor terpenting bagi pelanggan dalam sebuah proses penentuan pembelian sebuah produk.

c. Pada peneliti selanjutnya penulis menyarankan agar menambahkan beberapa variabel yang belum ditambahkan pada penelitian ini seperti Actual Attributes, Brand Image, Past Experience, Word of Mouth, Brand Swithing, Product Quality, Product Packaging, Brand Advertising dsb. Begitu juga variabel country of origin berperan pada kecocokan model namun tidak memoderasi hubungan antara ekuitas merek, preferensi merek dan minat pembelian. Peneliti selanjutnya dapat juga menambahkan variabel tersebut sebagai independen yang berpengaruh pada minat pembelian. Peneliti selanjutnya juga dapat melakukan penelitian pada sampel dan produk yang berbeda.

\section{Daftar Pustaka}

Aaker, D.A. (1991). Managing Brand Equity: Capitalizing on the value of a brand name. New York: The Free PressAgarwal, M.K. \& V.R. Rao, 1997. An empirical comparison of consumer-based measures of brand equity. Marketing Letter, 7, 237-247

Amran, K.M, Idrus, Setiawan, M., Armanu \& Djumahir (2015). Australian Journal of Basic and Applied Sciences, 9(31), 490-497

Awwad, Falah \& Ahmad, Ayesh. (2013). Effectiveness of Laptop Usage in UAE University Undergraduate Teaching. TOJET, 12(2), 77-88

Bilal, Muhammad \& Ali, Tahir. (2013). Factors Influencing Consumers Purchase Intentions towards Private Brands. JISR-MSSE,11(2), 18-21

Buil, I., Martinez, E., \& Chernatony, Leslie de. (2013). The Influence of Brand Equity on Consumer Responses. Journal of Consumer Marketing, 30(1), 62-74

Cheng, Huai-Pin \& Cheng, Huai-Tzu. (2013). The Influence of Brand and Price on Purchase Intention of Mobile Phone in the case of Taiwan College Students. Applied Mechanics and Materials, 411-414, 2326-2329

Choe, P. \& Zhao, Yi (2013). The Influence of Airline Brand on Purchase Intention of Air Tickets in China. Industrial Engineering \& Management Systems, 12(2), 143-150

Chou, Chieh-Min. (2013). Factors Affecting Purchase Intention of Online Game Prepayment Card - Evidence from Thailand. JIBC, 18(3), 1-14

Darakhshan, Nahid \& Islam, Jamid Ul. (2014). Purchase Intention and Buying Behavior towards Laptop: A study of students in Jamia Milia Islamia University, New Delhi, India. Retrived November 3, 2016 from URL:

de Chernaony, L., F. Harris, \& G. Christodoulides. (2004). Developing a brand performance measure for financial service brands. The Service Industries Journal, 24(2), 15-33

Fitch, J.L. (2004). Student Feedback in the college classroom: A technology Solution. Educational Technology Research and Development, 52, 171-181

Ghozali, Imam, 2006. Aplikasi Analisis Multivarite dengan SPSS, Cetakan Keempat. Semarang: Universitas Diponegoro

Ghozali, Imam, 2011. Aplikasi Analisis Multivariat dengan Program IBM SPSS 19. Edisi 5. Semarang: Universitas Diponegoro

Ghozali, Imam, 2013. Aplikasi Analisis Multivariat dengan Program IBM SPSS 21. Edisi 7. Semarang: Universitas Diponegoro

Grunert, Klaus, G., Lars Esbjerg, and Tino Brch Brch-larsen. (2006). Consumer preferences for retailer brand architectures: results from a conjoint study. International journal of retail and distribution management, 34(8), 597-608

Gujarati, Damodar N., Dawn C, Porter. 2013. Dasar-dasar Ekonometrika. Jakarta: Salemba Empat. 
Hair Jr, J.F., Black, W.C., Babin, B.J., Anderson, R.E. 2009. Multivariate Data Analysis Seventh Edition. USA: Pearson Education Limited.

Hartley, H.O., \& Pearson, E. S. 1966. Biometrika Tables for Statisticians Vol. I, 3. Auflage. University Press, Cambridge.

https://www.academia.edu/7871519/Purchase_Intention_and_Buying_Behavior_towards_Lap tops_A_study_of_students_in

Indriantoro, Nur., Bambang Supomo, 2006. Metodologi Penelitian Bisnis untuk Akuntansi dan Manajemen, Edisi Pertama. Yogyakarta : BPFE Yogyakarta

Irshad, Waseem (2012). Service Based Brand Equity, Measure of Purchase Intention, Mediating Role of Brand Performance. Academy of Contemporary Research Journal $1(1), 1-10$

Jaafar, S.N., Lalp, P.E., Naba, M.M. (2013). Consumers' Perceptions Attitude and Purchase Intention towards Private Label Food Products in Malaysia. Asian Journal of Business Management Sciences, 2(8), 73-90

Jalilvand, M.R., Samiei, N., Mahdavinia, S.H. (2011). The Effect of Brand Equity Components on Purchase Intention. International Business and Management, 2(2), 149158

Keller, K.L. (2003). Strategic brand management: Building, measuring and managing brand equity. Upper Saddle River, New Jersey, Pearson Education Inc.

Mahfooz, Yasser (2015). Brand Equity Consequence Relationship: Evidence from Automobile Industry. International Journal of Business and Management, 10(3), 81-90

Mirabi, V., Akbariyeh, H., \& Tahmasebifard, H. (2015). A Study of Factors Affecting on Customers Purchase Intention. JMEST, 2, 267-273

Moradi, H. \& Zarei, A. (2011). The Impact of Brand Equity on Purchase Intention and Brand Preference-the Moderating Effect of Country of Origin Image. Australian Journal of Basic and Applied Sciences, 5(3), 539-545

Munusamy, J. and Wong, C.H. (2008). Relationship between marketing mix strategy and consumer motive: an empirical study in major Tesco stores. UNITAR E-Journal, 4(2)

Mustafa, Hasan. 2009. Metodologi Penelitian. Cetakan kesepuluh. Jakarta: Bumi Aksara.

Myers, C. (2003). Managing Brand Equity: a look at the impact of attributes. Journal of Product \& Brand Management, 12, 39-51

Nazir, Moh., 2008. Metode Penelitian. Bogor: Ghalia Indonesia.

Prasad, K., \& C.S. Dev. (2000). Managing Hotel Brand Equity. Cornell Hotel and Restaurant Administration Quarterly, 41(3), 22-31

Rezvani, S., Dehkordi, G. J., Rahman, M. S., Fouladivanda, F., Habibi, M., \& Eghtebasi, S. (2012). A Conceptual Study on The Country of Origin Effect on Consumer Purchase Intention. Asian Social Science, 8(12), 205-215

Roozy, E., Arastoo, M.A., \& Vazifehdust, H. (2014). Effect of Brand Equity on Consumer Purchase Intention. Indian J.Sci.Res, 6(1), 212-217

Santoso, Cynthia R., \& Cahyadi, Tabita E. (2014). Analyzing the Impact of Brand Equity toward Purchase Intention in Automotive Industry: A Case Study of ABC Surabaya. iBuss Management, 2(2), 29-39

Sanyal, N.S., \& Datta, S.K. (2011). The Effect of Country of Origin on Brand Equity: An Empirical Study on Generic Drugs. Journal of Product \& Brand Management, 20(2), $130-140$

Saydan, Reha. (2013). Relationship between Country of Origin Image and Brand Equity: An Empirical Evidence in England Market. International Journal of Business and Social Science, 4(3), 78-88 
Shah, S.M., Adeel, M., Hanif, F., \& Khan, M. (2016). The Impact of Brand Equity on Purchase Intentions with Moderating Role of Subjective Norms. Universal Journal of Industrial and Business Management,4, 18-24. doi: 10.13189/ujibm.2016.040102.

Shahrokh, Z.D., Azodi, A.D., (2013). The Effect of Country of Origin Image on Brand Equity and Purchase Intention. Journal of Applied Environmental and Biological Sciences, 3(12), 52-61

Stephen, B.R. (2005). Laptop in psychology: Conducting flexible in-class research and writing laboratories. New Direction for Teaching and Learning, 101, 15-26

Sukandarrumidi \& Haryanto, 2008. Dasar-Dasar Penulisan Proposal Penelitian. Jogjakarta: Gadjah Mada University Press.

Suryadi, Davin. (2015). The Impact of Brand Equity toward Purchase Intention on PT. X's Candy. iBuss Management, 3(2), 1-8

Tih, S., Lee, K.H. (2013). Perceptions and Preditors of Consumers' Purchase Intention for Store Brands: Evidence from Malaysia. Asian Journal of Business and Accounting, 6(2), 107-136

Vinh, Tran T., Huy, Van Le. (2016). The Relationship among Brand Equity, Brand Preference and Purchase Intention: Empirical Evidence from the Motorbike in Vietnam. International Journal of Economics and Finance, 8(3), 77-84

Wang, Ya-Hui. (2015). Does Winning an Award Affect Investors' Brand Preference and Purchase Intention. International Journal of Management and Marketing Research, 8(1), 57-64

Yasin, N.M., Noor , M.N., Mohamad O. (2015). "Does Image of Country of Origin Matter to Brand Equity?". Journal of Product and Brand Management, 16(1), 38-48 